\title{
Efektivitas Pemanfaatan Komputer pada Kantor Pengadilan Tata Usaha Negara Makassar
}

\author{
Andi Agiskawati, Jamaluddin, Muh. Nasrullah, Rudi Salam \\ Pendidikan Administrasi Perkantoran, Universitas Negeri Makassar \\ Email: rudisalam@unm.ac.id
}

\begin{abstract}
Penelitian ini bertujuan untuk mengetahui Efektivitas Pemanfaatan Komputer pada Kantor Pengadilan Tata Usaha Negara Makassar. Penelitian ini merupakan penelitian Deskriptif Kuantitatif. Populasi penelitian ini adalah pegawa Kantor Pengadilan Tata Usaha Negara Makassar sebanyak 54 orang. Teknik pengumpulan data menggunakan teknik observasi, angket, wawancar dan dokumentasi. Teknik analisis data yang digunakan yaitu analisis persentase dalam tabel frekuensi. Hasil penelitian menunjukkan bahwa Efektivitas Pemanfaatan Komputer pada Kantor Pengadilan Tata Usaha Negara Makassar berada pada kategori Efektif, ditinjau dari indikator 1) Keberhasilan program dengan presentase 87,38\% berada pada kategori efektif, 2) Keberhasilan sasaran dengan presentase $87,04 \%$ berada pada kategori efektif, 3) Kepuasan terhadap program dengan presentase $85,88 \%$ berada pada kategori efektif, 4) Tingkat input dan output dengan presentase 89,81berada pada kategori efektif, dan 5) Pencapaian tujuan menyeluruh dengan presentase $86,92 \%$ berada pada kategori efektif.
\end{abstract}

Kata Kunci: Efektivitas, Pemanfaatan Komputer

\begin{abstract}
This study aims to determine the Effectiveness of Computer Use at the Makassar State Administrative Court. This research is quantitative descriptive. The population of this study was 54 people from the Makassar State Administrative Court. Data collection techniques using observation, questionnaire, interview and documentation techniques. Data analysis techniques used are percentage analysis in the frequency table. The results showed that the Effectiveness of Computer Use in the Makassar State Administrative Court was in the Effective category, in terms of indicator 1) The success of the program with a percentage of $87.38 \%$ was in the effective category, 2) The success of the target with a percentage of $87.04 \%$ was in the category effective, 3) Satisfaction with the program with a percentage of $85.88 \%$ in the effective category, 4) The level of input and output with a percentage of 89.81 is in the effective category, and 5) Achievement of the overall goal with a percentage of $86.92 \%$ is in the effective category.
\end{abstract}

Keywords: Effectiveness, Computer Utilization

\section{PENDAHULUAN}

Perkembangan teknologi belakangan ini sangatlah pesat dan sangat bermanfaat terhadap seluruh kegiatan yang dilakukan oleh organisasi. Dengan demikian, kebutuhan akan data dan 
14| Jurnal Office, Vol. 4, No. 1, Januari-Juni 2018

informasi dalam suatu organisasi sangat penting agar tujuan organisasi dapat tercapai. Perkembangan teknologi saat ini, mendorong setiap organisasi untuk mengolah datanya dengan cepat, lengkap dan akurat (Nasrullah, 2016; Saggaf, Salam, Kahar, \& Akib, 2014; Saragih \& Ramdhany, 2012). Salah satu teknologi yang dapat membantu dalam pengolahan data di dalam lingkungan organisasi adalah dengan menggunakan komputer.

Dengan bantuan komputer pekerjaan dapat dikerjakan dengan lebih cepat, mudah, bervariasi, bahkan pekerjaan-pekerjaan yang rumit dalam organisasi banyak mengalami perubahan dan kemudahan dengan menggunakan komputer. Komputer adalah Alat pengolah data elektronil, tidak bersifat mekanis (mesin), dan dapat merekan dan mengolah data dari yang sederhana sampai yang paling rumit menjadi informasi (Liu \& Xu, 2017; M. Wolf, 2017). Dengan munculnya teknologi komputer dan perkembangan pemakainya, maka setiap unit pekerjaan kantor menggunakan bantuan komputer. Penggunaan komputer juga dapat meningkatkan produktivitas dan efektivitas kerja serta efesiensi waktu (Achim \& Kassim, 2015; Fatimah \& Biswas, 2016; Kaizer, Heller, \& Oberkampf, 2015; Tarsitano, Del Corso, Ciocca, Scotti, \& Marchetti, 2015; Tate, Warschauer, \& Abedi, 2016; Yeşilyurt, Ulaş, \& Akan, 2016; Žumárová, 2015). Namun di dalam penelitian ini penulis lebih memfokuskan pemanfaatan komputer pada efektivitas kerja.

Efektivitas merupakan unsur pokok dalam mencapai tujuan atau sasaran yang telah ditentukan sebelumnya. Efektivitas adalah tercapainya berbagai sasaran yang telah ditentukan tepat pada waktunya dengan menggunakan sumber-sumber tertentu yang telah dialokasikan untuk melakukan berbagai kegiatan. Suatu pekerjaan dapat dikatakan efektif apabila hasil yang dicapai telah sesuai dengan tujuan yang telah ditetapkan sebelumnya dan tepat pada waktu yang telah ditentukan. Secara sederhana, efektivitas kerja dapat didefenisikan sebagai kemampuan melakukan sesuatu tepat pada sasarannya.

Semakin efektifnya kerja para pegawai dapat menjadikan organisasi semakin tangguh mencapai tujuannya dan berbagai sasarannya. Dengan adanya pemanfaatan komputer yang baik, maka suatu organisasi semakin mampu berperan dengan tingkat efektivitas yang tinggi dan dapat memenuhi kebutuhan-kebutuhan data dan informasi untuk unit-unit fungsional organisasi pemerintah, serta dalam menetapkan berbagai kebijakan pemerintah dan perencanaan pembangunan, baik pada tingkat konseptual maupun pada tingkat operasional diperlukan adanya berbagai data dan informasi yang akurat, tepat dan cepat guna pengambilan keputusan sejalan dengan tingkat perkembangan yang semakin maju.

Berdasarkan pengamatan awal yang dilakukan oleh peneliti selama melaksanakan Praktek Perkantoran pada tanggal 12 Juni 2017 sampai dengan 11 Agustus 2017 di kantor Pengadilan Tata Usaha Negara Makassar ada berbagai hambatan atau kendala-kendala yang dihadapi beberapa pegawai dalam melaksanakan pekerjaannya, misalnya dalam proses penggunaan komputer tidak semua pegawai dapat menggunakannya. Untuk meningkatkan efektivitas kerja pegawai yang kurang memahami tentang pemanfaatan komputer ini maka pihak instansi pemerintahan harus mengupayakan berbagai usaha supaya pegawai dapat mengetahui penggunaan komputer, agar tidak terjadi suatu pengalihan kinerja dari satu pegawai ke pegawai yang lainnya. Maksudnya ialah pegawai yang kurang memahami penggunaan komputer melimpahkan tugasnya ke pegawai lain sehingga pegawai lainnya mendapatkan pekerjaan tambahan, maka dari itu pekerjaan utama pegawai tersebut bisa terganggu akibat adanya 
Andi Agiskawati, Jamaluddin, Muh. Nasrullah, Rudi Salam; Efektivitas Pemanfaatan Komputer.... $\mid 15$

perintah dari pegawai lainnya. Hal tersebut dapat mengurangi efektivitas kerja pegawai dalam pemanfaatan komputer.

\section{METODE}

Penelitian ini menggunakan pendekatan kuantitatif dengan jenis penelitian deskriptif yang digunakan untuk menggambarkan tentang bagaiman efektivitas pemanfaatan komputer pada Kantor Pengadilan Tata Usaha Negara Makassar. Penelitian ini menggunakan teknik analisis deskriptif dengan menggunakan tabel frekuensi dan persentase. Dalam pengukuran variabel penelitian ini menggunakan angket berskala Likerst yang akan diisi oleh responden sesuai dengan indikator variabel. Populasi pada penelitian ini yaitu pegawai pada Kantor Pengadilan Tata Usaha Negara Makassar dengan jumlah populasi sebanyak 54 pegawai, peneliti mengambil semua populasi sebagai subjek penelitian sehingga penelitian ini merupakan penelitian populasi. Adapun pengumpulan data pada penelitian ini menggunakan teknik angket, wawancara, observasi dan dokumentasi. Dan data angket yang terkumpul akan dianalisis dengan menggunakan tabel frekuensi dan persentase.

\section{HASIL PENELITIAN DAN PEMBAHASAN}

Analisis data dalam penelitian ini menggunakan metode manual dengan menggunakan tabel frekuensi dan persentase. Adapun perolehan analisis data efektivitas pemanfaatan komputer yang sekaligus menjadi indicator. Untuk lebih jelasnya dapat dilihat pada tabel 1.

Tabel 1.

Analisis Statistik Deskriptif

\begin{tabular}{|c|l|c|c|c|c|}
\hline No. & Indikator & $\mathbf{n}$ & $\mathbf{N}$ & $\mathbf{\%}$ & Kategori \\
\hline 1. & Keberhasilan program & 755 & 864 & 87,38 & Efektif \\
\hline 2. & Keberhasilan sasaran & 752 & 864 & 87,04 & Efektif \\
\hline 3. & Kepuasan terhadap program & 742 & 864 & 85,88 & Efektif \\
\hline 4. & Tingkat Input dan Output & 776 & 864 & 89,81 & Efektif \\
\hline 5. & Pencapain tujuan menyeluruh & 751 & 864 & 86,92 & Efektif \\
\hline \multicolumn{2}{|}{ Jumlah } & $\mathbf{3 7 7 6}$ & $\mathbf{4 3 2 0}$ & $\mathbf{8 7 , 4 1}$ & Efektif \\
\hline
\end{tabular}

Adapun gambaran dari pengumpulan data dengan menggunakan kelima indikator tersebut diperoleh hasil sebagai berikut:

\section{Keberhasilan Program}

Hasil olahan data yang dirumuskan indikator keberhasilan program pada Kantor Pengadilan Tata Usaha Negara Makassar berada pada kategori efektif dengan hasil perolehan $87,38 \%$ berada pada rentang nilai $76 \%$ - 100\%. Sesuai dengan teori keberhasilan program atau kemampuan organisasi ataupun perusahaan untuk mencapai target yang telah diprogramkan sebelumnya. Hal ini dapat dilihat bahwa pegawai mampu memanfaatkan komputer dengan 
16| Jurnal Office, Vol. 4, No. 1, Januari-Juni 2018

prosedur dan mekanisme yang baik dan menggunakan komputer tersebut dalam menyelesaikan pekerjaan yang telah ditentukan sebelumnya, dapat meningkatkan kemampuan oprasional para pegawai, serta menghemat waktu dan biaya dalam proses dan mekanisme suatu tujuan kegiatan dengan memanfaatkan komputer tersebut.

\section{Keberhasilan Sasaran}

Hasil olahan data yang dirumuskan indikator keberhasilan sasaran pada Kantor Pengadilan Tata Usaha Negara Makassar berada pada kategori efektif dengan hasil perolehan $87,04 \%$ berada pada rentang nilai $76 \%-100 \%$. Sesuai dengan teori keberhasilan sasaran dalam hal ini kemampuan dilihat dari target atau sasaran yang telah ditentukan sebelumnya. Hal ini dapat dibuktikan dengan pemanfaatan komputer untuk mencapai sasaran yang telah ditentukan pada Kantor Pengadilan Tata Usaha Negara Makassar mengalami peningkatan dalam mencapai target atau sasaran untuk membuktikan hal tersebut para pegawai diberikan kemudahan dalam menyelesaikan pekerjaannya dengan memanfaatkan komputer.

\section{Kepuasan terhadap Program}

Hasil olahan data yang dirumuskan indikator kepuasan terhadap program pada Kantor Pengadilan Tata Usaha Negara Makassar berada pada kategori efektif dengan hasil perolehan $85,88 \%$ berada pada rentang nilai $76 \%-100 \%$. Sesuai dengan teori kepuasan terhadap program yang merupakan tingkat rasa puas atas peranan atau pekerjaan yang telah dilakukan dalam organisasi atau perusahaan. Hal ini dapat dibuktikan bahwa kepuasan terhadap hasil yang telah diprogramkan sebelumnya dengan memanfaatkan komputer sebagai alat dalam mencapai hasil tersebut memberikan hasil yang memuaskan dan memberikan dampak baik dibandingkan dengan menyelesaikan tugas tanpa memanfaatkan komputer.

\section{Tingkat Input dan Output}

Hasil olahan data yang dirumuskan indikator tingkat input dan output pada Kantor Pengadilan Tata Usaha Negara Makassar berada pada kategori efektif dengan hasil perolehan $89,81 \%$ berada pada rentang nilai $76 \%-100 \%$. Sesuai dengan teori tingkat input dan output yakni input pengukuran yang mengutamakan adanya keberhasilan organisasi untuk mencapai hasil output yang sesuai dengan rencana. Hal ini dapat dibuktikan bahwa para pegawai pada Kantor Pengadilan Tata Usaha Negara Makassar mengolah data yang diberikan atau mengimput data tersebut agar menghasilkan output yang baik sehingga hasil yang telah direncanakan sesuai dengan target yang ditentukan.

\section{Pencapaian Tujuan Menyeluruh}

Hasil olahan data yang dirumuskan indikator keberhasilan tujuan menyeluruh pada Kantor Pengadilan Tata Usaha Negara Makassar berada pada kategori efektif dengan hasil perolehan $86,92 \%$ berada pada rentang nilai $76 \%$ - $100 \%$. Sesuai dengan teori pencapaian tujuan menyeluruh untuk melihat sejauh mana pelaksanaan program dari semua kegiatan yang 
Andi Agiskawati, Jamaluddin, Muh. Nasrullah, Rudi Salam; Efektivitas Pemanfaatan Komputer.... $\mid 17$

telah dicapai. Hal ini dapat dibuktikan bahwa dengan memanfaatkan komputer selalu memberikan hasil yang dapat diterima oleh semua pegawai dan tujuan yang ingin dicapai dapat terlaksana sesuai dengan program kegiatan yang direncanakan. Para pegawai mampu mengimplementasika pemanfaatan komputer dengan mengetahui cara mengoprasikannya.

\section{SIMPULAN}

Berdasarkan hasil penelitian, dapat disimpulkan bahwa Mahasiswa Program Studi Pendidikan Administrasi Perkantoran Fakultas Ilmu Sosial Universitas Negeri Makassar berminat untuk menjadi guru. Hal ini dapat dilihat dari hasil yang diperoleh dari setiap indikator pada variabel ini, yaitu: 1) Kognisi (mengenal), dimana hasil penelitian menunjukkan bahwa kognisi (mengenal) yaitu pengetahuan dan informasi mengenai profesi guru berada pada kategori sangat berminat dengan persentase 82,96 persen, 2) Emosi (perasaan), dimana hasil penelitian menunjukkan bahwa emosi (perasaan) yaitu perasaan senang, ketertarikan dan perhatian yang besar terhadap profesi guru berada pada kategori berminat dengan persentase 75,85 persen, dan 3) Konasi (kehendak), dimana hasil penelitian menunjukkan bahwa konasi (kehendak) yaitu hasrat, kemauan dan motivasi menjadi guru berada pada kategori berminat dengan persentase 65,16 persen.

\section{DAFTAR PUSTAKA}

Achim, N., \& Kassim, A. Al. (2015). Computer Usage: The Impact of Computer Anxiety and Computer Self-efficacy. Procedia - Social and Behavioral Sciences, 172, 701-708. https://doi.org/https://doi.org/10.1016/j.sbspro.2015.01.422

Fatimah, Y. A., \& Biswas, W. K. (2016). Sustainability Assessment of Remanufactured $\begin{array}{llll}\text { Computers. } & \text { Procedia } & \text { CIRP, } & \text { 150-155. }\end{array}$ https://doi.org/https://doi.org/10.1016/j.procir.2016.01.087

Kaizer, J. S., Heller, A. K., \& Oberkampf, W. L. (2015). Scientific computer simulation review. Reliability Engineering \& System Safety, 138, 210-218. https://doi.org/https://doi.org/10.1016/j.ress.2015.01.020

Liu, C., \& Xu, X. (2017). Cyber-physical Machine Tool - The Era of Machine Tool 4.0. Procedia CIRP, 63, 70-75. https://doi.org/https://doi.org/10.1016/j.procir.2017.03.078

Nasrullah, M. (2016). Implementasi Sistem Informasi Manajemen Berbasis Teknologi Informasi Di Universitas Negeri Makassar. Jurnal Ilmiah Ilmu Administrasi Publik, 5(2), 53-63.

Saggaf, S., Salam, R., Kahar, F., \& Akib, H. (2014). Pelayanan Fungsi Administrasi Perkantoran Modern. Jurnal Ad'ministrare, 1(1), 20-27.

Saragih, H., \& Ramdhany, R. (2012). Pengaruh intensi pelanggan dalam berbelanja online kembali melalui media teknologi informasi forum jual beli (FJB) Kaskus. Jurnal Sistem Informasi, 8(2), 100-112. 
18| Jurnal Office, Vol. 4, No. 1, Januari-Juni 2018

Tarsitano, A., Del Corso, G., Ciocca, L., Scotti, R., \& Marchetti, C. (2015). Mandibular reconstructions using computer-aided design/computer-aided manufacturing: A systematic review of a defect-based reconstructive algorithm. Journal of Cranio-Maxillofacial Surgery, 43(9), 1785-1791. https://doi.org/https://doi.org/10.1016/j.jcms.2015.08.006

Tate, T. P., Warschauer, M., \& Abedi, J. (2016). The effects of prior computer use on computerbased writing: The 2011 NAEP writing assessment. Computers \& Education, 101, 115131. https://doi.org/https://doi.org/10.1016/j.compedu.2016.06.001

Wolf, M. (2017). Chapter 1 - Electronic Computers. In M. B. T.-T. P. of C. Wolf (Ed.) (hal. 111). Boston: Morgan Kaufmann. https://doi.org/https://doi.org/10.1016/B978-0-12809381-8.00001-8

Yeşilyurt, E., Ulaş, A. H., \& Akan, D. (2016). Teacher self-efficacy, academic self-efficacy, and computer self-efficacy as predictors of attitude toward applying computer-supported education. Computers in Human Behavior, 64, 591-601. https://doi.org/https://doi.org/10.1016/j.chb.2016.07.038

Žumárová, M. (2015). Computers and Children's Leisure Time. Procedia - Social and Behavioral Sciences, 176, 779-786. https://doi.org/https://doi.org/10.1016/j.sbspro.2015.01.540 